DOI https://doi.org/10.15589/znp2020.2(480).2

УДК $629.5 .03 ; 629.5 .015 .4 ; 004.942$

\title{
DETERMINATION OF LOADS ACTING ON THE SHAFTING WHEN SHIP DOES NOT MOVE AND DURING ITS MOVEMENT ON WAVES
}

\section{ВИЗНАЧЕННЯ НАВАНТАЖЕННЯ, ЩО ДІЕ НА ВАЛОПРОВІД ПІД ЧАС СТОЯНКИ СУДНА ТА ЙОГО РУХУ НА ХВИЛЮВАННІ}

\author{
Oleksandr I. Ursolov \\ oleksandr.ursolov@nuos.edu.ua \\ ORCID: 0000-0003-4079-3415
}

\author{
О. І. Урсолов, \\ аспірант
}

\author{
Admiral Makarov National University of Shipbuilding, Mykolaiv \\ Національний університет кораблебудування імені адмірала Макарова, м. Миколаїв
}

\begin{abstract}
The main reasons for the marine propulsion shafting and its bearings failures include the imperfection of its bending calculation models and lack of considering its operation during the ship motions on the waves at the stage of shaft alignment calculation. Existing approaches to taking into account the impact of waves are limited to considering only the hydrodynamic forces on the propeller or the bending of the vessel caused by the static regular wave. A method for shafting bending calculation simultaneously in the vertical and horizontal planes as a multi-span non-prismatic beam lying on an inhomogeneous nonlinear one-sided Winkler elastic foundation has been developed proving more accurate modeling the marine propulsion shafting bending compared to the common model of the beam on the nodal supports due to more advanced bearing model. The basis of the new approach is the finite element method and the division of the bent shafting line into two solutions, namely the bending only from the bearing offsets and only from the deformation of the elastic foundation. A method for determining the loads acting on the shafting during a joint operation of the ship - shafting system when the ship does not move and during its movement on intensive irregular waves has been developed. The mathematical model includes the equations of the hydrodynamic sea keeping theory, the irregular waves spectral theory, expressions for inertial forces acting on the shafting caused by ship motions, the lifting surface theory for calculating hydrodynamic forces on the propeller, the equations of girder bending and shear as a non-prismatic beam, the finite element method for calculating bending of the engine room bottom grillage and shafting. Based on the developed shafting operational model, test calculations for a containership were carried out. The analysis of the impact of inertial forces, hydrodynamic loads on the propeller, general and local hull deformations in waves conditions on the shafting operation is carried out. The results of the study showed that during ship motions, hydrodynamic loads on the propeller and inertial forces have the most effect on the stern tube bearing's load, inertial forces have the most effect on the intermediate bearings' load. It was also found that the hull deformations caused by ship motions on the waves have a little effect on the bearing load, but have a significant effect on the misalignment of the bearings.

Key words: propulsion complex; ship motions; marine propulsion shafting bending; elastic foundation; mathematical model.
\end{abstract}

\footnotetext{
Анотація. До основних причин аварійності суднових валопроводів та їх підшипників можна віднести недосконалість розрахункових моделей згину валопроводу та нерозглядання на етапі розрахунку центрування валопроводу режимів його роботи під час руху судна на хвилюванні. Існуючі підходи до врахування впливу хвилювання обмежуються розгляданням лише гідродинамічних сил на гребному гвинті або згину судна за статичної постаноки на хвилю. Розроблено метод розрахунку статичного згину валопроводу водночас у вертикальній та горизонтальній площинах, як багатопрогонової непризматичної балки, що лежить на неоднорідній нелінійній односторонній зміщуваній пружній основі Вінклера, який точніше моделює згин суднового валопроводу порівняно з поширеною моделлю балки на вузлових опорах завдяки більш досконалій моделі підшипника. Основою нового підходу є метод скінчених елементів та розділення згину на два розв'язки, а саме згин лише від зміщення підшипників та лише від деформування пружної основи. Розроблено метод визначення навантажень, які діють на валопровід за сумісної роботи системи судно - валопровід в умовах стоянки судна та його руху на інтенсивному нерегулярному хвилюванні. У математичну модель входять рівняння гідродинамічної теорії хитавиці, спектральної теорії нерегулярного хвилювання, вирази для інерційних сил, що діють на валопровід від хитавиці, теорії несучої поверхні для розрахунку гідродинамічних сил на гребному гвинті, рівняння згину та зсуву еквівалентного бруса як непризматичної балки, вирази методу скінченних елементів для розрахунку згину днищового перекриття машинного відділення та згину валопроводу. Проведено тестові розрахунки на розробленій моделі функціонування валопроводу на прикладі контейнеровоза. Проведено аналіз впливу інерційних сил, гідродинамічних навантажень на гребний гвинт та загальних і місцевих деформацій корпусу в умовах хвилювання на роботу валопроводу. Результати дослідження показали, що під час хитавиці основний вплив на навантаження дейдвудного
} 
підшипника здійснюють гідродинамічні сили на гребному гвинті й інерційні сили, а на навантаження проміжних підшипників найбільше впливають інерційні сили. Також було визначено, що деформації корпусу судна на хвилях мало впливають на навантаження підшипників, але мають значний вплив на розцентрування валів у підшипниках.

Ключові слова: пропульсивний комплекс; хитавиця судна; згин суднового валопроводу; пружна основа; математична модель.

\section{ПОСТАНОВКА ЗАДАЧІ}

Аналіз аварійності суднових валопроводів показав, що втомні руйнування валів, перегрівання, плавління, надтирання і втомне руйнування дейдвудних підшипників із бабіту, а також інтенсивне зношення неметалевих дейдвудних підшипників, що змащуються водою, $\epsilon$ досить частими причинами аварій на суднах. Причиною цих аварій часом $\epsilon$ неякісне центрування валопроводу або неупереджений на функціонування судна в умовах хвилювання вибір параметрів центрування, оскільки зазвичай розглядається лише робота валопроводу за номінальної потужності головного двигуна й експлуатації судна на тихій воді. Причиною аварій також є нераціональний вибір параметрів валопроводу, зумовлений недосконалістю розрахункових схем.

\section{АНАЛІЗ ОСТАННІХ ДОСЛІДЖЕНЬ I ПУБЛІКАЦЙ}

У більшості досліджень статичного згину валопроводу застосовуються розрахункові схеми 3 дейдвудними підшипниками, що представлені однією, двома або декількома вузловими опорами, які не відображають його континуальну природу. Існує низку робіт із моделювання дейдвудного підшипника пружною основою, але вони мають суттєві недоліки, як-от постійна жорсткість пружної основи за довжиною та ії незалежність від прогину вала, згин лише у вертикальній площині, відсутність поперечних зміщень пружної основи тощо. Варто відзначити великий вклад Ю.П. Кочанова й інших [1] в дослідження напружено-деформованого стану дейдвудних опор і моделювання їх за допомогою пружної основи.

Існують малочисельні експериментальні дослідження [2], які показують значний вплив хитавиці на напружено-деформований стан валопроводу. У багатьох теоретичних дослідженнях лише визначаються гідродинамічні навантаження на гребний гвинт під час хитавиці [3-5] або визначаються зміщення підшипників за статичної постаноки судна на хвилю [4; 6], а інерційні сили від хитавиці враховувались лише в [7].

\section{ВІДОКРЕМЛЕННЯ НЕ ВИРІШЕНИХ РАНІШЕ ЧАСТИН ЗАГАЛЬНОЇ ПРОБЛЕМИ}

Більш точні моделі роботи суднового валопроводу та розрахункові схеми його напружено-деформованих станів дозволять передбачати можливі ризики майбутньої експлуатації валопроводу й уточнювати його конструктивні розміри під час проєктування судна або параметри центрування на існуючих судах. Крім того, режими роботи валопроводу в умовах хитавиці судна на хвилях натепер найменш вивчені, отже, мають бути досліджені більш детально.

\section{МЕТА ДОСЛІДЖЕННЯ}

Метою статті $є$ вдосконалення розрахункової моделі роботи валопроводу для розрахунків його центрування, розроблення моделі роботи системи судно - валопровід за руху судна на хвилях.

\section{МЕТОДИ, ОБ'ЄКТ ТА ПРЕДМЕТ ДОСЛІДЖЕННЯ}

Усі стани валопроводу, що розглядаються в розрахунках центрування, можна умовно розділити на статичні й експлуатаційні, відповідно підходи до розрахункових схем також мають певні відмінності.

Автором розроблено метод розрахунку статичного згину валопроводу одночасно у вертикальній та горизонтальній площинах, який враховує довжину, зазор і деформацію вкладишів, а також лінійні та кутові зміщення підшипників в обох площинах. Система рівнянь статичного згину валопроводу як багатопрогонової непризматичної балки з урахуванням деформацій зсуву, що лежить на неоднорідній нелінійній односторонній зміщуваній пружній основі Вінклера, у диференційній формі має вигляд:

$$
\left\{\begin{array}{l}
{\left[E I_{y}(x) u_{z}^{\prime \prime}\right]^{\prime \prime}+k\left(x, u_{y}, u_{z}\right) u_{z}-\left[\frac{E I_{y}(x)}{G A_{z}^{*}(x)} k\left(x, u_{y}, u_{z}\right) u_{z}\right]^{\prime \prime}=q_{z}(x)-\left[\frac{E I_{y}(x)}{G A_{z}^{*}(x)} q_{z}(x)\right]^{\prime \prime}} \\
{\left[E I_{z}(x) u_{y}^{\prime \prime}\right]^{\prime \prime}+k\left(x, u_{y}, u_{z}\right) u_{y}-\left[\frac{E I_{z}(x)}{G A_{y}^{*}(x)} k\left(x, u_{y}, u_{z}\right) u_{y}\right]^{\prime \prime}=q_{y}(x)-\left[\frac{E I_{z}(x)}{G A_{y}^{*}(x)} q_{y}(x)\right]^{\prime \prime}}
\end{array}\right.
$$

де $u_{z}$ та $u_{y}$ - прогини балки вздовж осей $z$ та $y$ відповідно, $\boldsymbol{M} ; k$ - коефіцієнт жорсткості пружної основи, Н/м²; $q_{z}$ та $q_{y}$ - проєкції розподілених зовнішні сил на осі $z$ та $y$ відповідно, Н/м. Усі підшипники валопроводу можуть мати лінійні та кутові зміщен- ня у вертикальній та горизонтальній площинах, а також кутові зміщення. Жорсткість пружної основи $k(x, u z, u y)$ залежить від прогинів вала, тому є нелінійною, а також змінюється за довжиною підшипника, тобто є неоднорідною. 
Для описаної математичної моделі неможливо отримати точні аналітичні розв'язки системи диференційних рівнянь (1). Для розв'язання цієї системи 3 лінійною пружною основою в роботі використано метод скінченних елементів у його лінійній постановці [8] із застосуванням матриці жорсткості пружної основи з параболічною жорсткістю вздовж елемента [9], а нелінійність ураховується методом послідовних наближень із використанням розробленої автором релаксації [10].

Для заданих ексцентриситету вала е та його напрямку $\varphi$ коефіцієнт жорсткості пружної основи в перерізі підшипника має вигляд:

$$
k(x)= \begin{cases}r_{\mathrm{ef}}(x) / u_{r \max }(x) & \text { якщо } e(x)>0,5 \Delta, \\ 0 & \text { якщо } e(x) \leq 0,5 \Delta,\end{cases}
$$

де $\operatorname{urmax}(\mathrm{x})=\max (0 ; \mathrm{e}(\mathrm{x})-0,5 \Delta)-$ максимальне вдавлювання вала в підшипник у перерізі, м; - реакція перерізу підшипника, $\mathrm{H} / \mathrm{m} ; \Delta$ - діаметральний зазор підшипника, м.
Статичний згин валопроводу u розраховується як суперпозиція двох розв'язків (рис. 1): згин uoff від жорсткого зміщення вузлових опор у межах підшипника на його поверхні (пружна основа відсутня); згин uef на пружній основі від зовнішніх сил та реактивних навантажень від жорсткого зміщення підшипників за розрахунку uoff (вузлові опори в межах пружної основи відсутні). На рис. 2 показано приклад розрахунку статичного згину валопроводу 3 використанням розробленого підходу.

Для розрахунку згину суднового валопроводу 3 урахуванням змащення в декількох або всіх його підшипниках під час руху судна й обертання валопроводу в роботі використано метод, що описано в [11].

Розроблено узагальнену модель функціонування валопроводу з урахуванням його взаємодії з корпусом судна за його руху на тихій воді та в умовах нерегулярного хвилювання (рис. 3). Серед внутрішніх чинників ураховано нелінійну взаємодію валопроводу 3 його підшипниками за центрування судна або стоянки, а також взаємодію через гідродинамічне змащен-

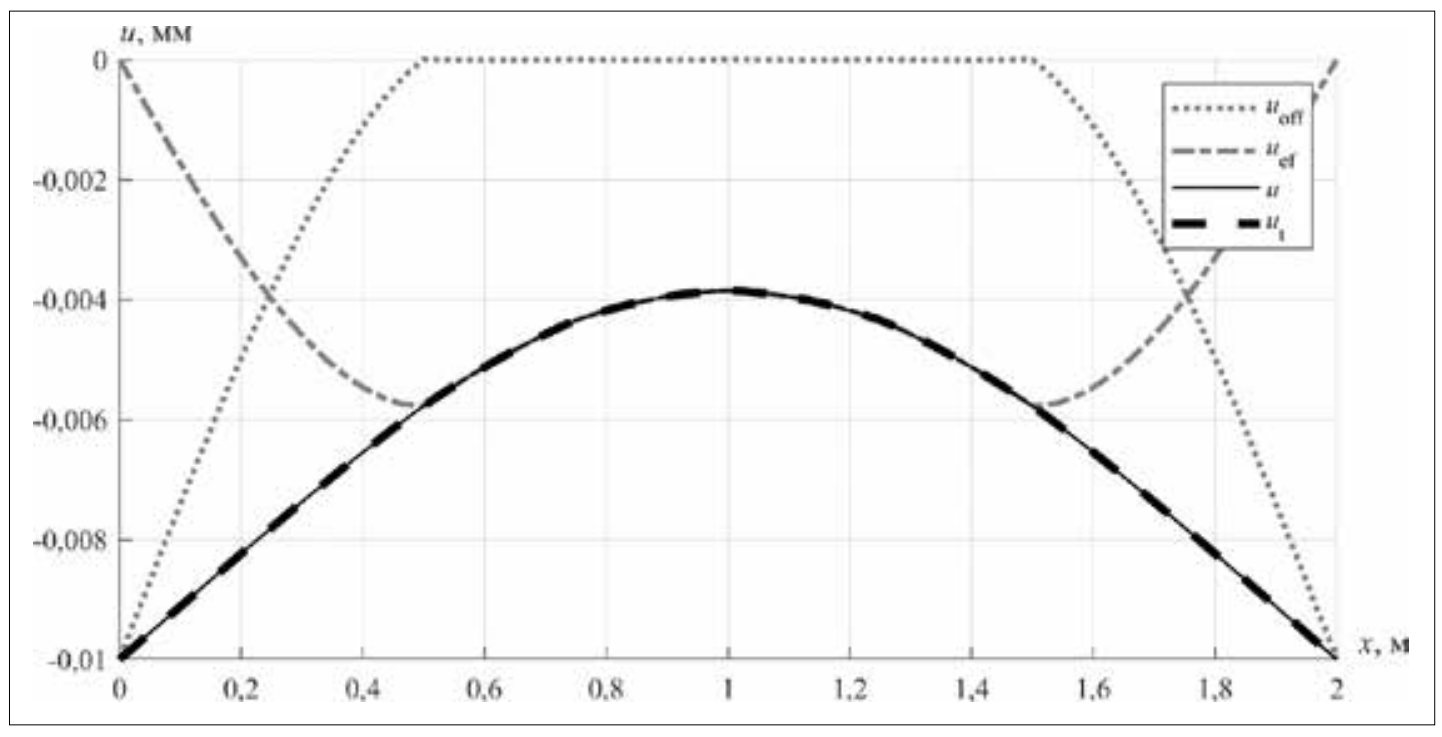

Рис. 1. Згин балки на пружній основі зі зміщенням

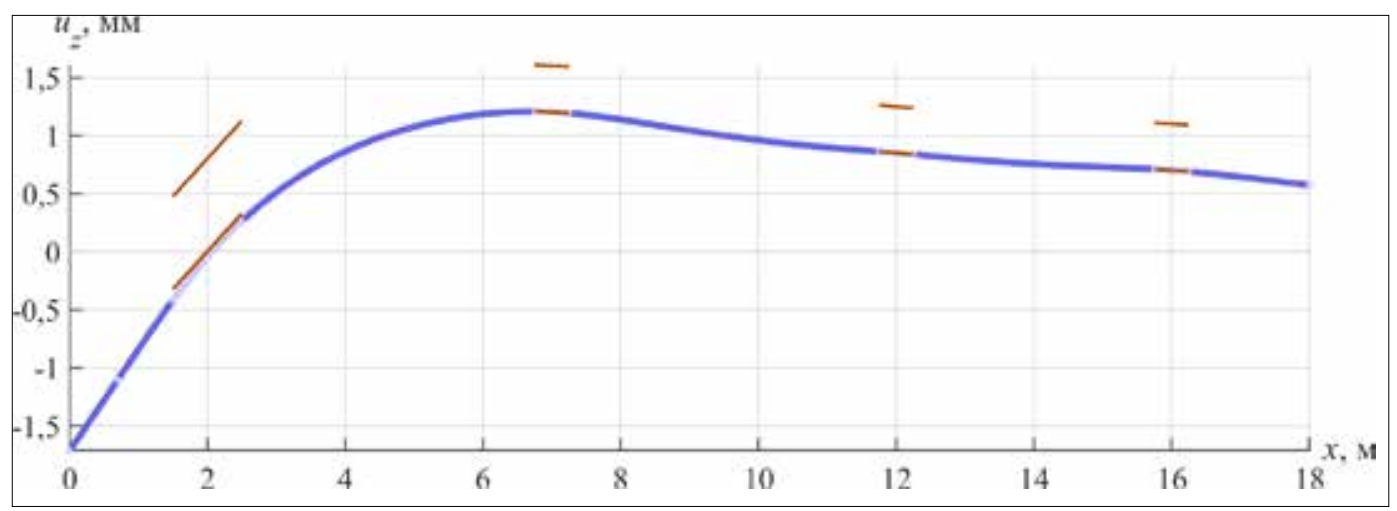

Рис. 2. Статичний згин відцентрованого валопроводу 


\section{СУДНОБУДУВАННЯ №2 2020}

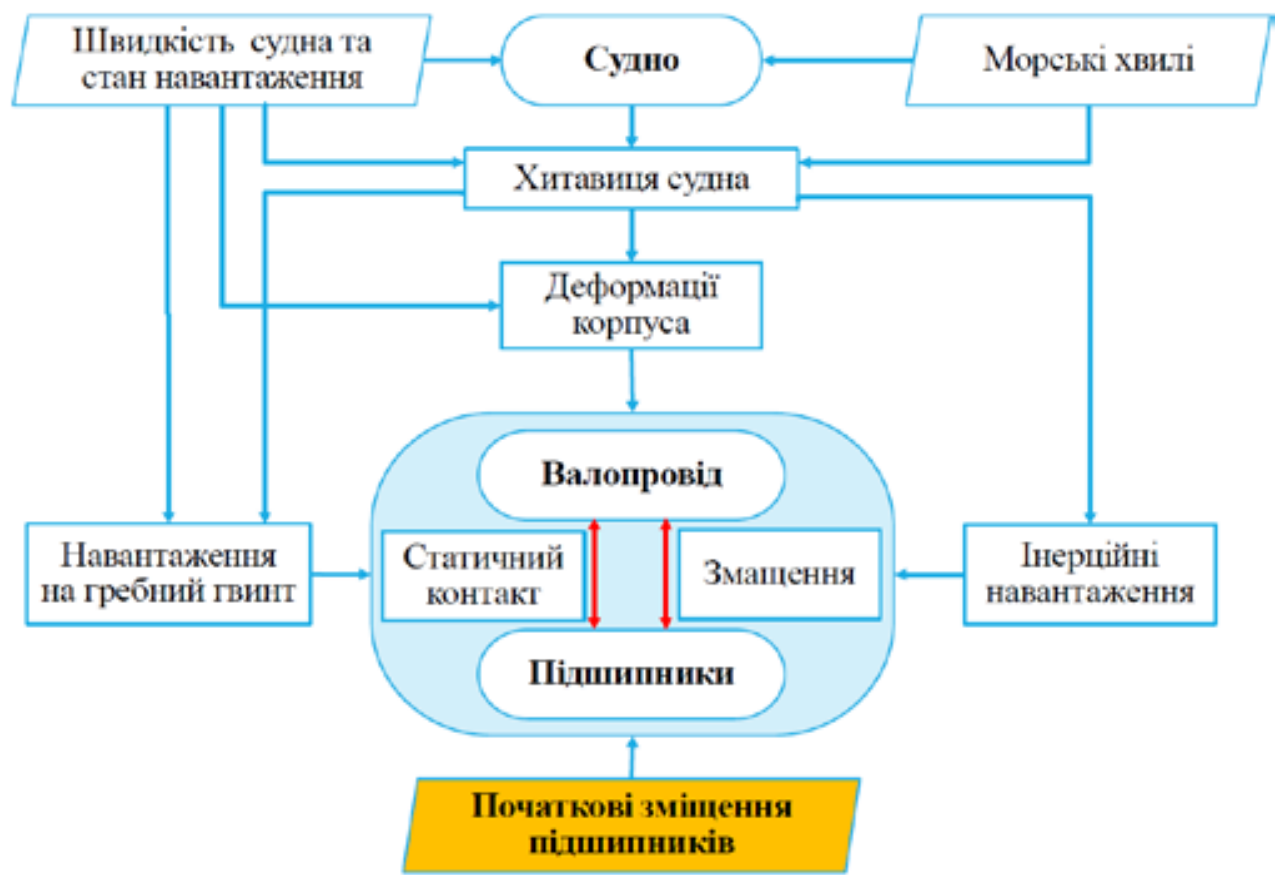

Рис. 3. Схема математичної моделі роботи системи судно - валопровід

ня в підшипниках у разі руху судна. Серед зовнішніх чинників ураховано вплив гідродинамічних навантажень на гребний гвинт на тихій воді та під час хитавиці судна, загальних і місцевих деформацій корпусу від зміни посадки судна та хвильових навантажень, а також інерційних сил від хитавиці. Основними параметрами системи $є$ посадка судна, швидкість його руху та стан моря.

Розрахунок хитавиці судна на нерегулярному морському хвилюванні в часовій області виконується на основі гідродинамічної теорії хитавиці [12] та спектральної теорії нерегулярного хвилювання.

Як спектр морського хвилювання використано JONSWAP [13], основними вихідними даними для якого є значна висота хвилі h1/3 і середній період хвилювання $T$. Спектральна щільність дискретизується 3 використанням рандомізації для зменшення мінімально необхідної довжини реалізації.

Розподілені інерційні навантаження на елементи валопроводу визначаються за формулою $q_{\text {in }}(x)=-m(x) a_{\zeta}(x), \quad$ а сконцентровані навантаження (наприклад на гребний гвинт, що представлений сконцентрованою масою) - за формулою $F_{\text {in }}=-M a_{\zeta}(x)$, де $m(x)$ - розподілена маса елемента валопроводу, кг/м; $M$ - маса елемента валопроводу, кг; $a_{\zeta}(x)$ - вертикальні прискорення на осі валопроводу $з$ координатою $x$, м/ $\mathrm{c}^{2}$.

Для розрахунку гідродинамічних сил та моментів, що діють на гребний гвинт під час руху судна на тихій воді та на хвилях, у роботі застосовано метод «схема A» [5], що заснований на теорії несучої поверхні. Хитавиця судна враховується шляхом додаткових осьових та дотичних швидкостей у диску гвинта на основі скосу потоку. Урахування хвилювання здій- снюється додатковими швидкостями потенційного руху хвиль у диску гвинта [12].

Для розрахунку згину судна в роботі використовується модель еквівалентного бруса як непризматичної безопорної балки [14]. Для розрахунку прогину днищового перекриття машинного відділення в роботі використано метод скінченних елементів у стержневій ідеалізації [8], який забезпечує компроміс між точністю результатів та швидкістю розрахунку.

\section{ОСНОВНИЙ МАТЕРІАЛ}

Проведено тестові розрахунки на розробленій моделі функціонування валопроводу на прикладі контейнеровоза 4400 TEU довжиною 280 м. Досліджувались режими хвилювання 3 наступними значними висотами хвиль $h_{1 / 3}=0,6 ; 1,8 ; 4,3 ; 7,9 ; 11,6$; 14,0 м, які відповідають 3-, 4-, 6-, 7-, 8- і 9-бальному стану моря. Проведено аналіз впливу окремих зовнішніх чинників під час хитавиці на роботу валопроводу (рис. 4, у дужках наведено навантаження на підшипники на тихій воді).

\section{ОБГОВОРЕННЯ ОТРИМАНИХ РЕЗУЛЬТАТІВ}

Результати дослідження показали, що під час хитавиці основний вплив на навантаження дейдвудного підшипника здійснюють гідродинамічні сили на гребному гвинті й інерційні сили, а на навантаження проміжних підшипників найбільше впливають інерційні сили. Величини додаткових вертикальних навантажень на підшипники під час хитавиці мають найбільші значення для дейдвудного підшипника. На другому 3 корми підшипнику вплив хитавиці менше, але 3 тенденцією до розвантаження. На другому і третьому підшипниках із корми вплив хитавиці незначний. 3 ростом висоти хвилі збільшується амплітуда додаткових 


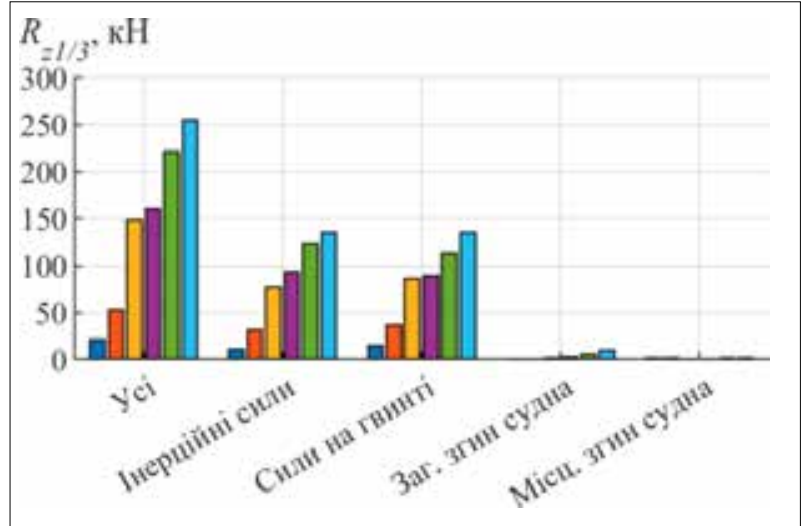

a) дейдвудний підшипник (843,6 кН)

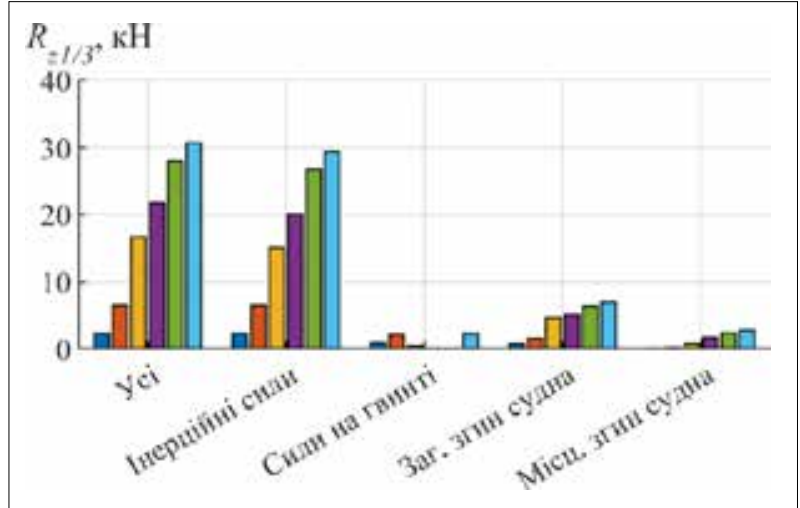

в) 2 проміжний підшипник (268,7 кН)

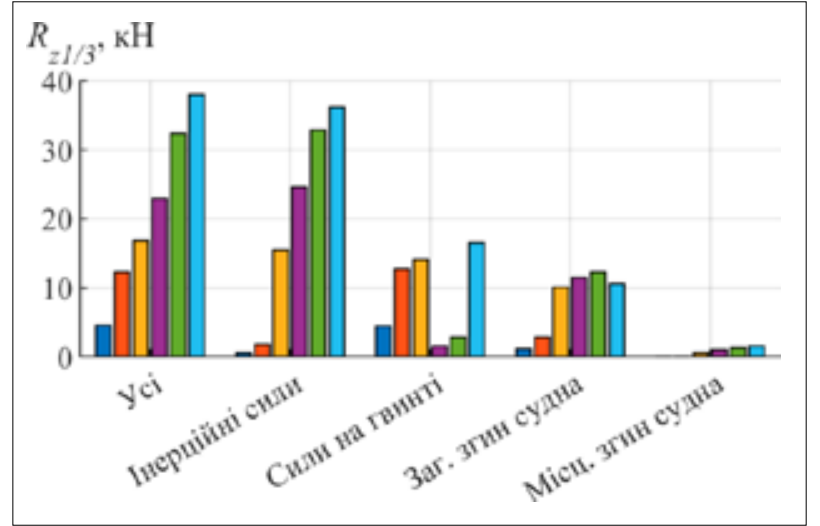

б) 1 проміжний підшипник (218,3 кН)

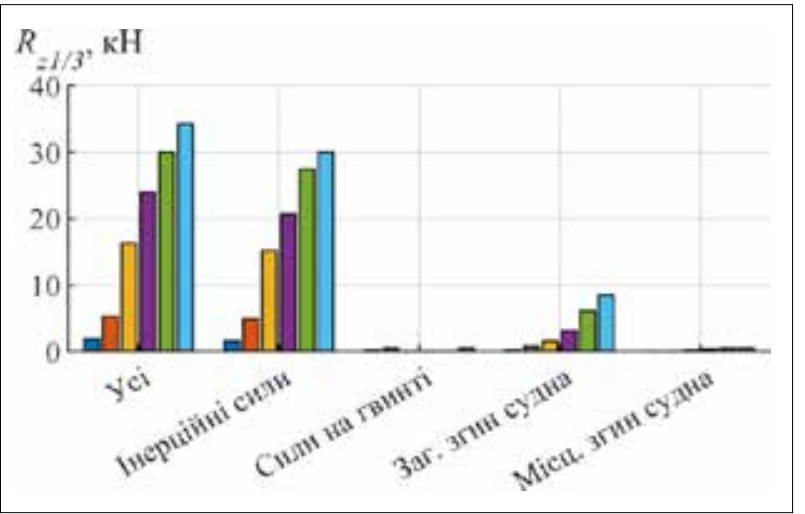

2) 3 проміжний підшипник (292,8 кН)

Рис. 5. Вплив різних факторів на додаткові навантаження дейдвудного та проміжних підшипників, спричинених хвилюванням

як вертикальних, так і горизонтальних навантажень на підшипники. Основним джерелом додаткових горизонтальних навантажень $є$ горизонтальний гідродинамічний згинальний момент на гребному гвинті. Найбільші величини горизонтальних навантажень мають місце на перших двох підшипниках.

Деформації корпусу мало впливають на навантаження підшипників, але мають значний вплив на розцентрування валів. Значне розцентрування шийок валів у вертикальній площині можна спостерігати в усіх підшипниках, а його амплітуди під час інтенсивного шторму можуть досягати 0,2 мм/м. Значне розцентрування в горизонтальній площині має місце лише в дейдвудному підшипнику та значно менше у другому підшипнику. Варто зазначити, що вплив деформацій корпусу може залежати від типу судна, конструкції машинного відділення та валопроводу.

\section{ВИСНОВКИ}

1. За допомогою методу скінченних елементів удосконалено метод розрахунку статичного згину суднового валопроводу, підшипники якого представлені односторонньої неоднорідною нелінійною зміщуваною пружною основою, що дозволило врахувати довжину, зазор, деформування та зміщення підшипників.

2. Уперше на основі використання методів теорії корабля, будівельної механіки корабля та гідродинамічної теорії змащення розроблено комплексну модель динаміки системи судно - валопровід за руху судна на хвилюванні, яка враховує діючі на валопровід гідродинамічні сили на гребному гвинті, інерційні сили від хитавиці судна, сили від деформування корпусу судна на хвилях та гідродинамічне змащення в підшипниках гребного вала.

3. За допомогою отриманої моделі функціонування системи судно - валопровід уперше розроблено комплексний метод розрахунку діючих на валопровід статичних та динамічних навантажень, які необхідно враховувати на стадіях проєктування валопроводу та вибору параметрів його центрування.

4. Розроблені методи будуть впроваджені у спеціалізоване програмне забезпечення ShaftDesigner для розрахунку центрування та вібрації суднових валопроводів [15].

\section{REFERENCES}

[1] Kochanov, Yu.P., Paplauskas, A.R., Telehyna, Y.A. (1988) Yssledovanye y razrabotka metodyky rascheta napriazhenyi v elementakh tiazhelonahruzhennikh opor s kompensatoramy nesoosnosty valov. Nykolaev: NKY. [in Russian].

[2] Merkulov, V.A., \& Pasumanskyi, E.M. (1984). Raschet prochnosty hrebnikh valov s uchetom yzghybaiushchykh usylyi, obuslovlennikh kachkoi sudov. Sudostroenye, 7, 19-22. [in Russian]. 


\section{СУДНОБУДУВАННЯ №2 2020}

[3] Lypys, V.B. (1975). Hydrodynamyka hrebnoho vynta pry kachke sudna. Lenynhrad: Sudostroenye. [in Russian].

[4] Lure, Y.A. (1973). Yssledovanye hydrodynamycheskykh faktorov, opredeliaiushchykh velychyni nestatsyonarnikh nahruzok, peredavaemikh ot hrebnoho vynta na valoprovod pry kachke y razrabotka metoda rascheta dolhovechnosty hrebnikh valov. Predpryiatye p/ya V-8662. [in Russian].

[5] OST 5.4268-78 Vynti hrebnie. Metodyka rascheta hydrodynamycheskykh usylyi na hrebnikh vyntakh, rabotaiushchykh v neravnomernom potoke za korpusom sudna. (1978). [in Russian].

[6] Jinming, L., Ding, L. (2010). Calculation the Influence of Ocean Waves on Shafting Based on 3-D FEM. 2010 International Conference on Digital Manufacturing \& Automation. Washington, DC: IEEE Computer Society.

[7] Ursolov, A.Y., Nekrasov, V.A. (2019). Statystycheskaia otsenka ynertsyonnikh nahruzok na podshypnyky valoprovoda sudna pry prodolnoi kachke na nerehuliarnom volnenyy. Naukovyi visnyk Khersonskoi derzhavnoi morskoi akademii, 2 (21), 67-76. [in Russian].

[8] Postnov, V.A., Kharkhurym, Y.Ya. (1974). Metod konechnikh elementov v raschetakh sudovikh konstruktsyi. Lenynhrad: Sudostroenye. [in Russian].

[9] Ursolov, O.I., Batrak, Yu.A. (2019). Matrytsia zhorstkosti stryzhnevoho skinchennoho elementa na pruzhnii osnovi z neliniinoiu zhorstkistiu uzdovzh elementa. Problemy obchysliuvalnoi mekhaniky i mitsnosti konstruktsii, 29, 207-220. [in Ukrainian]

[10] Ursolov, A.Y. (2019) Reshenye zadach tsentrovky valoprovoda s obratnimy sviaziamy obobshchennim metodom relaksatsyy. Visnyk Odeskoho natsionalnoho morskoho universytetu, 2 (59), 91-106. [in Russian]

[11] Ursolov, A., Batrak, Y., Tarelko, W. (2019). Application of the optimization methods to the search of marine propulsion shafting global equilibrium in running condition. Polish Maritime Research, 3 (103), 172-180.

[12] Remez, Yu.V. (1983). Kachka korablia. Lenynhrad: Sudostroenye. [in Russian].

[13] Hesselmann, D.E., Dunkel, M., \& Ewing, J.A. (1980). Directional spectra observes during JONSWAP 1973. Journal of Physical Oceanology, 10, 1264-1284.

[14] Korotkyn, Y.Ya., Rostovtsev, D.M., Syvers, N.L. (1974). Prochnost korablia. Lenynhrad: Sudostroenye. [in Russian]

[15] ShaftDesigner - The Shaft Calculation Software by IMT. (2020). Retrieved from https://shaftdesigner.software/.

\section{СПИСОК ВИКОРИСТАНОЇ ЛІТЕРАТУРИ}

[1] Исследование и разработка методики расчёта напряжений в элементах тяжело нагруженных опор с компенсаторами несоосности валов / Ю.П. Кочанов и др. Николаев : НКИ, 1988.

[2] Меркулов В.А., Пасуманский Е.М. Расчет прочности гребных валов с учетом изгибающих усилий, обусловленных качкой судов. Судостроение. 1984. № 7. С. 19-22.

[3] Липис В.Б. Гидродинамика гребного винта при качке судна. Ленинград : Судостроение, 1975.

[4] Лурье И.А. Исследование гидродинамических факторов, определяющих величины нестационарных нагрузок, передаваемых от гребного винта на валопровод при качке и разработка метода расчёта долговечности гребных валов. Предприятие п/я В-8662. 1973.

[5] ОСТ 5.4268-78. Винты гребные. Методика расчёта гидродинамических усилий на гребных винтах, работающих в неравномерном потоке за корпусом судна. 1978.

[6] Jinming, L., Ding, L. Calculation the Influence of Ocean Waves on Shafting Based on 3-D FEM. International Conference on Digital Manufacturing \& Automation. Washington, DC : IEEE Computer Society, 2010.

[7] Урсолов А.И., Некрасов В.А. Статистическая оценка инерционных нагрузок на подшипники валопровода судна при продольной качке на нерегулярном волнении. Науковий вісник Херсонської державної морської академії. 2019. № 2 (21). С. 67-76.

[8] Постнов В.А., Хархурим И.Я. Метод конечных элементов в расчетах судовых конструкций. Ленинград : Судостроение, 1974.

[9] Урсолов О.І., Батрак Ю.А. Матриця жорсткості стрижневого скінченного елемента на пружній основі з нелінійною жорсткістю уздовж елемента. Проблеми обчислювальної механіки і міцності конструкцій. 2019. № 29. С. $207-220$.

[10] Урсолов А.И. Решение задач центровки валопровода с обратными связями обобщённым методом релаксации. Вісник Одеського національного морського університету. 2019. № 2 (59). С. 91-106.

[11] Ursolov A., Batrak Y., Tarelko W. Application of the optimization methods to the search of marine propulsion shafting global equilibrium in running condition. Polish Maritime Research. 2019. № 3 (103). C. 172-180.

[12] Ремез Ю.В. Качка корабля. Ленинград : Судостроение, 1983.

[13] Hesselmann D.E., Dunkel M., Ewing J.A. Directional spectra observes during JONSWAP 1973. Journal of Physical Oceanology. 1980. № 10. C. 1264-1284.

[14] Короткин И.Я., Ростовцев Д.М., Сиверс Н.Л. Прочность корабля. Ленинград : Судостроение, 1974.

[15] ShaftDesigner - The Shaft Calculation Software by IMT. 2020. URL: https://shaftdesigner.software/. 